\title{
PEMBERLAKUAN KETENTUAN PASAL 21 UNDANG-UNDANG NOMOR 30 TAHUN 2014 DALAM PENANGANAN KORUPSI
}

\author{
Y. Sri Pudyatmoko \\ Fakultas Hukum Universitas Atma Jaya Yogyakarta \\ email: sri.pudyatmoko@uajy.ac.id \\ G. Aryadi \\ Fakultas Hukum Universitas Atma Jaya Yogyakarta \\ email: g.aryadi@uajy.ac.id \\ disampaikan 09/03/2020 - di-review 29/07/2020 - diterima 16/11/2021 \\ DOI: $10.25123 /$ vej.v7i2.3780
}

\begin{abstract}
This research departs from the author's observation that Indonesian government officials are currently very wary and worried being criminally charged for corruption and at the same time brought before the administrative court for abuse of power. The main question here is whether the possibility of being brought before the Administrative Court may or may not have positive effect. The main finding, using a legal normative approach, is that the final decision on the issue, whether there is abuse of power or not, as decided by the Administrative Court, would be important in proving disproving, the corruption
\end{abstract} charge brought before the criminal court.

Keywords: abuse of power; administrative court; corruption.

\begin{abstract}
Abstrak
Penelitian ini berangkat dari pengamatan adanya kecemasan pejabat pemerintah akan tersangkut tindak pidana korupsi dan sekaligus gugatan dihadapan Pengadilan Tata Usaha Negara (PTUN), karena dipersalahkan menyalahgunakan kewenangan. Pokok kajian di sini adalah apakah kemungkinan dihadapkan pada PTUN memberikan dampak positif atau tidak. Temuan utama penelitian yuridis normatif ini adalah bahwa putusan akhir PTUN perihal ada-tidaknya penyalahgunaan kewenangan, akan penting dalam pembuktian unsur melawan hukum dalam kasus korupsi adalah apakah justeru pengujian dugaan terjadi penyalahgunaan kewenangan dihadapan PTUN memberikan manfaat positif bagi upaya pencegahan korupsi. Temuan dari kajian hukum yang dilakukan menunjukkan adanya manfaat positif tersebut, terutama bila tuduhan tindak pidana korupsi terkait berkelindan dengan tudingan terjadi penyalahgunaan kewenangan.
\end{abstract}

Kata kunci: penyalahgunaan wewenang; PTUN; korupsi.

\section{Pendahuluan}

Pejabat pemerintah dilengkapi dengan kewenangan untuk melaksanakan tugas dan kewajibannya. Kewenangan tersebut menjadi dasar dalam bertindak dan mengambil keputusan. Dalam menjalankan aktivitas pemerintahan, seorang pejabat 
pemerintahan/badan tata usaha negara sejatinya menjadi personifikasi negara karena dalam dirinya tersemat "jabatan" sebagai sumber otoritas representasi negara yang absah. ${ }^{1}$

Tidak jarang dalam pengambilan keputusan pejabat pemerintah diduga melakukan penyalahgunaan wewenang dengan menggunakan otoritas yang ada. Terhadap dugaan seperti itu pejabat yang tidak menerima, bisa menggunakan ketentuan dalam Pasal 21 Undang-Undang Nomor 30 Tahun 2014 tentang Administrasi Pemerintahan (UU Administrasi Pemerintahan) untuk mengajukan pengujian dugaan penyalahgunaan wewenang. Dalam undang-undang tersebut penyalahgunaan wewenang mempunyai cakupan yang begitu luas karena dapat meliputi:
a. melampaui Wewenang;
b. mencampuradukkan Wewenang; dan/atau
c. bertindak sewenang-wenang.

Ketentuan tersebut dapat terkait dengan korupsi, sebagaimana diatur dalam Pasal 3 Undang-Undang Nomor 31 Tahun 1999 tentang Pemberantasan Tindak Pidana Korupsi (UU Pemberantasan Tipikor) yang menentukan bahwa setiap orang yang dengan tujuan menguntungkan diri sendiri atau orang lain atau suatu korporasi, menyalahgunakan kewenangan, kesempatan atau sarana yang ada padanya karena jabatan atau kedudukan yang dapat merugikan keuangan negara atau perekonomian negara. Demikian juga dalam Pasal 12 huruf e Undang-Undang Nomor 20 Tahun 2001 juga diatur mengenai hal yang berkaitan dengan tindak pidana korupsi, yang menyebutkan bahwa pegawai negeri atau penyelenggara negara yang dengan maksud menguntungkan diri sendiri atau orang lain secara melawan hukum, atau dengan menyalahgunakan kekuasaannya memaksa seseorang memberikan sesuatu, membayar, atau menerima pembayaran dengan potongan, atau untuk mengerjakan sesuatu bagi dirinya sendiri. Dari rumusan kedua Pasal tersebut jelas terlihat bahwa penyalahgunaan wewenang merupakan

1 Fathudin, Tindak Pidana Korupsi (Dugaan Penyalahgunaan Wewenang) Pejabat Publik (Perspektif Undang-Undang Nomor 30 Tahun 2014 Tentang Administrasi Pemerintahan), II, Jurnal Cita Hukum, 2015, hlm. 120. 
sesuatu yang penting dalam tindak pidana korupsi. Terkait hal tersebut pengujian penyalahgunaan wewenang merupakan sesuatu hal yang penting di dalam soal korupsi tersebut.

Pemberantasan korupsi merupakan hal yang sangat penting bagi jalannya pemerintahan dalam rangka kelangsungan sebuah negara, karena korupsi menjadi penyakit yang tidak saja merugikan keuangan negara akan tetapi juga bagi masyarakat. Mengingat korupsi yang merambah semua lini pemerintahan, maka upaya pemberantasan mesti dilakukan dengan baik.

Dalam penyelenggaraan pemerintahan sering terjadi pejabat pemerintah ragu atau takut mengambil keputusan karena khawatir apabila dianggap keliru, menyalahgunakan wewenang dan berakibat pada proses hukum yang merugikan pejabat tersebut, akibatnya penyerapan terhadap anggaran dapat terhambat. Ketentuan Pasal 21 Undang-Undang UU Administrasi Pemerintahan diharapkan dapat menjembatani pengujian terhadap hal tersebut.

Mendasarkan kenyataan yang berkembang sebagaimana telah diuraikan, maka permasalahan yang diangkat dalam tulisan ini adalah, apakah ketentuan yang ada di dalam Pasal 21 UU Administrasi Pemerintahan dapat mengatasi kekhawatiran dari pejabat pemerintah terhadap penyalahgunaan wewenang dan terjebak pada praktek korupsi? Apakah ketentuan dalam Pasal 21 UU Administrasi Pemerintahan berpengaruh positif atau sebaliknya membawa pengaruh negatif terhadap penyelesaian kasus korupsi? Penelitian ini menggunakan metode penelitian hukum normatif dengan pendekatan peraturan perundang-undangan dan politik hukum.

\section{Pembahasan}

\section{Penyalahgunaan Wewenang dan Pengujiannya}

Tidak bisa disangkal bahwa salah satu persoalan besar yang dihadapi bangsa ini adalah soal korupsi. Rifyal Ka'bah mencatat bahwa sekurangnya ada 3 hal yang menyebabkan mengapa korupsi menarik untuk dibahas, yakni: ${ }^{2}$

2 Rifyal Ka'bah, Korupsi Di Indonesia,37, Jurnal Hukum dan Pembangunan, 2007, hlm. 78-79. 
a. menyangkut uang rakyat atau harta negara yang harus digunakan sesuai kehendak rakyat atau peraturan perundang-undangan yang dibuat negara.

b. penyakit masyarakat yang akan menghancurkan sebuah negara bila tidak segera dibendung.

c. melibatkan orang-orang yang seharusnya menjadi panutan masyarakat karena mereka adalah tokoh yang dipilih dan terpilih, dari kalangan terpelajar.

Dengan mendasarkan ketentuan dalam UU Pemberantasan Tipikor, Bambang Waluyo mencatat setidaknya ada 8 (delapan) kelompok delik korupsi, yaitu: ${ }^{3}$

a. Kelompok delik yang dapat merugikan keuangan negara atau perekonomian negara;

b. Kelompok delik penyuapan (aktif maupun pasif);

c. Kelompok delik penggelapan dalam jabatan;

d. Kelompok delik pemerasan dalam jabatan (knevelarij, extortion);

e. Kelompok delik pemalsuan;

f. Kelompok delik berkaitan dengan pemborongan, leveransir, dan rekanan;

g. Kelompok delik gratifikasi;

h. Kelompok delik yang merintangi dan menghalang-halangi penanganan perkara korupsi.

Dalam kaitannya dengan korupsi yang dilakukan oleh penyelenggara negara, berdasarkan profesi/jabatan, menurut laporan KPK dari tahun 2004 yang menduduki tiga besar urutan tertinggi dilakukan oleh anggota DPR/DPRD, Pejabat Eselon I/II/III, dan Kepala Daerah. ${ }^{4}$ Hal ini tentu merupakan sesuatu hal yang penting untuk mendapat perhatian. Dari gambaran tersebut selain kalangan legislatif, juga terdapat pejabat struktural yang menduduki Eselon pada urutan kedua. Ini tentu berkaitan dengan penggunaan kewenangan yang dipegangnya, yang disalahgunakan sehingga bisa menimbulkan kerugian keuangan negara.

3 Bambang Waluyo, Optimalisasi Pemberantasan Korupsi Di Indonesia, 1, 2, Jurnal Yuridis, 2014, hlm. 171-172.

4 https://www.kpk.go.id/id/statistik/penindakan/tpk-berdasarkan-profesi-jabatan/diakses tanggal 19 Februari 2020, pukul 12.00 WIB. 
Menurut Philipus M Hajon, dalam kepustakaan hukum administrasi Belanda, masalah wewenang selalu menjadi bagian yang begitu penting dan bagian awal dari Hukum Administrasi, karena objek Hukum Administrasi adalah wewenang. Kewenangan atau wewenang memiliki kedudukan yang penting dalm kajian Hukum Tata Negara dan Hukum Administrasi. ${ }^{5}$ Mengingat pentingnya kedudukan wewenang ini sehingga F.A.M. Stroink dan J.G. Steenbeek menyatakan: "Het begrip bevoegdheid is dan ook een kernbegrip in het staats en administratief recht" (Konsep kompetensi karenanya merupakan konsep inti dalam Hukum Tata Negara dan Hukum Administrasi) ${ }^{6}$

Istilah wewenang atau kewenangan disejajarkan dengan "authority" dalam bahasa Inggris dan "bevoegdheid" dalam bahasa Belanda. Authority dalam Black 'S Law Dictionary, diartikan sebagai Legal power; a right to command or to act; the right and power of public officers to require obedience to their orders lawfully issued in scope of their public duties. ${ }^{7}$

Phillipus M. Hadjon memberikan catatan berkaitan dengan penggunaan istilah "wewenang" dan "bevoegdheid". Istilah "bevoegdheid" digunakan dalam konsep hukum privat dan hukum publik, sedangkan "wewenang" selalu digunakan dalam konsep hukum publik. ${ }^{8}$ Dalam kaitanya dengan pembuatan keputusan Tata Usaha Negara, kewenangan menjadi kunci penting sebagaimana diatur dalam Pasal 52 ayat (1) a UU Administrasi Pemerintahan.

Penyalahgunaan wewenang merupakan konsep yang ada dalam hukum administrasi, yang banyak menimbulkan salah paham dalam memahaminya. Dalam praktiknya penyalahgunaan wewenang sering dimaknai sebagai penyalahgunaan sarana dan kesempatan, yang dilakukan secara melawan hukum (werrechtelijkheid, onrechtmatige daad), atau bahkan memperluasnya

5 Philipus M Hadjon, Tatiek Sri Djalmiati, Hukum Administrasi dan Tindak Pidana Korupsi, Gadjahmada University Press, Yogyakarta, 2011, hlm.10.

6 Stroink, F.A.M. dan J.G. Steenbeek, Inleiding in het StaatsenAdministrastief Rech. Alphen aan den Rijn: Samsom H.D. TjeenkWilink, 1985, hlm. 26.

$7 \quad$ Henry Campbell Black, M. A., Black's Law Dictionary, St. Paul, Minn. West Publishing Co. 1990, hlm. 133. Edisi Keenam.

8 Philipus M Hadjon, Tentang Wewenang, http://journal.unair.ac.id/download-fullpapersyuridika557e071ab6full.pdf. diakses tanggal 07 Februari 2020, pukul 16.00 WIB. 
dengan setiap tindakan yang melanggar aturan atau kebijakan apapun dan di bidang apapun. Dengan penggunaan konsep luas dan bebas ini, akan mudah menjadi senjata penyalahgunaan wewenang yang lain dan justru menjadikan kebebasan bertindak pemerintah dalam menghadapi situasi konkret (freies ermessen) menjadi tidak ada artinya. ${ }^{9}$ Dengan mengambil dari Verklarend Woordenboek Openbaar Bestuur bahwa penyalahgunaan wewenang (detournement de pouvoir) adalah penggunaan wewenang tidak sebagaimana mestinya. Dalam hal ini pejabat menggunakan wewenangnya untuk tujuan lain yang menyimpang dari tujuan yang telah diberikan kepada wewenang itu. ${ }^{10}$ Untuk mengukur apakah telah terjadi penyalahgunaan wewenang haruslah dibuktikan secara faktual bahwa pejabat telah menggunakan wewenangnya untuk tujuan lain. Terjadinya penyalahgunaan wewenang bukanlah karena kealpaan. Penyalahgunaan wewenang dilakukan secara sadar yaitu mengalihkan tujuan yang telah diberikan kepada wewenang itu yang didasarkan atas kepentingan pribadi, baik untuk kepentingan dirinya sendiri ataupun untuk orang lain. ${ }^{11}$

Digunakannya "tujuan dan maksud" pemberian wewenang untuk menentukan ada tidaknya penyalahgunaan wewenang dikenal dengan asas spesialitas (specialiteitsbeginsel). ${ }^{12}$ Dalam soal ini yang menjadi penentu adalah hal yang berada di dalam diri si pengambil keputusan. Yang mempunyai maksud dan tujuan ataupun kehendak, tentu si pejabat sebagai pelaku pengambi keputusan itu.

Pendapat yang agak terperinci mengenai penyalahgunaan wewenang disampaikan oleh Jean Rivero dan Waline. Menurut mereka penyalahgunaan wewenang dalam hukum administrasi terdiri atas 3 (tiga) bentuk yaitu:

\footnotetext{
$9 \quad$ Supandi. Hukum Peradilan Tata Usaha Negara. Alumni, Bandung, 2016. hlm. 423.

10 Philipus M. Hadjon et.al Hukum Administrasi dan Good Governance, Penerbit Universitas Trisakti, Jakarta . 2012. hlm. 25-26.

11 Philipus M. Hadjon et.al. Supra note 5. hlm. 22.

12 Nur Basuki Minarno, Penyalahgunaan Wewenang dalam Pengelolaan Keuangan Daerah yang Berimplikasi Tindak Pidana Korupsi, Laksbang Mediatama, Surabaya, 2011. hlm. 97.
} 
a) Penyalahgunaan wewenang untuk melakukan tindakan-tindakan yang bertentangan dengan kepentingan umum untuk menguntungkan kepentingan pribadi, kelompok atau golongan

b) Penyalahgunaan wewenang dalam arti tindakan penjabat tersebut adalah benar diajukan untuk kepentingan umum, tetapi menyimpang dari tujuan apa kewenangan tersebut diberikan oleh undang-undang atau peraturanperaturan lainnya

c) Penyalahgunaan wewenang dalam arti penyalahgunaan prosedur yang seharusnya dipergunakan untuk mencapai tujuan tertentu, tetapi telah menggunakan prosedur lain agar terlaksana. ${ }^{13}$

Penyalahgunaan wewenang dapat diuji melalui pengadilan di lingkungan Peradilan Tata Usaha Negara berdasar Pasal 53 ayat (2) huruf b Undang-Undang Nomor 5 Tahun 1986 tentang Peradilan Tata Usaha Negara (UU PTUN). Dalam hal ini penyalahgunaan wewenang diartikan sebagai "menggunakan wewenangnya untuk tujuan lain dari maksud diberikannya wewenang tersebut."

Dalam penjelasan Pasal tersebut antara lain disebutkan bahwa penerapan ketentuan tersebut harus selalu sesuai dengan tujuan dan maksud khusus diadakannya peraturan yang bersangkutan. Ketentuan tersebut kemudian mengalami perubahan setelah lahirnya Undang-Undang Nomor 9 Tahun 2004 tentang Perubahan atas Undang-Undang Nomor 5 Tahun 1986. Dalam UndangUndang ini tidak disebutkan lagi adanya penyalahgunaan wewenang.

Perkembangan pengaturan mengenai pengujian terhadap penyalahgunaan wewenang itu terjadi setelah lahirnya UU Administrasi Pemerintahan, khususnya dalam Pasal 21 Undang-Undang tersebut, yang mana pejabat pemerintahan dapat mengajukan permohonan untuk menguji ada tidaknya penyalahgunaan terhadap keputusa yang diputusnya. Pengadilan TUN diberi waktu maksimal 21 untuk menyatakan ada tidaknya penyalahgunaan wewenang tersebut. Hasil dari pengujian itu ditentukan di dalam Pasal 19 UU Administrasi Pemerintahan. Pejabat yang tidak puas atas Putusan Pengadilan TUN dapat mengajukan banding

13 Indriyanto Seno Adji, Korupsi, Kebijakan Aparatur Negara dan Hukum Pidana, Diadit Media, Jakarta, 2009, hlm. 35. 
ke Pengadilan Tinggi TUN. Pengadilan Tinggi TUN diberi waktu 21 hari untuk memutuskan banding tersebut, dan putusan Pengadilan Tinggi TUN tersebut berlaku final.

Lahirnya UU Administrasi Pemerintahan dapat dikatakan merubah tatanan dalam pengujian terhadap keputusan tata usaha negara yang mengandung penyalahgunaan wewenang. Sementara pihak mengkhawatirkan bahwa aturan tersebut akan mempengaruhi dalam penegakan hukum terhadap tindak pidana korupsi, mengingat penyalahgunaan wewenang menjadi salah satu unsur di dalam tindak pidana korupsi. Ukuran penyalahgunaan wewenang terdapat dalam Pasal 17 ayat (2) UU Administrasi Pemerintahan yang meliputi:

a. larangan melampaui Wewenang;

b. larangan mencampuradukkan Wewenang; dan/atau

c. larangan bertindak sewenang-wenang.

Hal tersebut kiranya membawa perubahan terhadap apa yang ditentukan dalam UU PTUN, karena penyalahgunaan wewenang dan kesewenang-wenangan itu dalam UU PTUN dibedakan. Apa yang sudah diatur dalam Pasal 17 UU Administrasi Pemerintahan tersebut kemudian diuraikan dalam Pasal 18.

Pasal 19 UU Administrasi Pemerintahan menentukan bahwa Keputusan dan/atau Tindakan yang ditetapkan dan/atau dilakukan dengan melampaui Wewenang serta Keputusan dan/atau Tindakan yang ditetapkan dan/atau dilakukan secara sewenang-wenang tidak sah apabila telah diuji dan ada Putusan Pengadilan yang berkekuatan hukum tetap. Ketentuan ini menunjukkan adanya asas praduga rechtsmatig (praduga keabsahan), yakni sepanjang belum diputus atau dinyatakan sebaliknya, maka semua keputusan dan/atau tindakan badan atau pejabat pemerintahan senantiasa dianggap sah. Ketidakabsahan itu baru bisa dikatakan ada apabila pengadilan telah mengujinya dan kemudian menyatakan sebagai tidak sah.

Untuk penanganan terhadap permohonan pengujian penyalahgunaan wewenang yang diajukan ke Pengadilan Tata Usaha Negara, Mahkamah Agung telah mengeluarkan Peraturan Mahkamah Agung (Perma) Nomor 4 Tahun 2015. Pasal 1 butir 5 Perma tersebut menentukan bahwa Permohonan adalah 
permintaan yang diajukan secara tertulis kepada Pengadilan untuk menilai ada atau tidak ada unsur penyalahgunaan wewenang yang dilakukan oleh Badan dan/atau Pejabat Pemerintahan dalam keputusan dan/atau tindakan. Ketentuan tersebut menggambarkan bahwa menurut Mahkamah Agung pemeriksaan untuk menguji ada tidaknya penyalahgunaan wewenang berdasarkan Pasal 21 UU Administrasi Pemerintahan itu dilakukan hanya sebagai tindak lanjut hasil pemeriksaan, dan bukan pengujian yang dilakukan atas inisiatif dari pejabat yang membuat keputusan tersebut sebelum dipersoalkan pihak lain. Ketentuan tersebut juga sekaligus menegaskan 2 hal yakni:

a. bahwa hasil pengawasan dari aparatur pengawas internal, bisa jadi merupakan keputusan yang menyatakan adanya penyalahgunaan wewenang oleh pejabat pemerintahan, bukan merupakan objek yang dipersoalkan di PTUN berdasar Pasal 21 Undang-Undang Administrasi Pemerintahan.

b. Permohonan yang didasarkan Pasal 21 UU Administrasi Pemerintahan bukan merupakan gugatan. Berdasar ketentuan Pasal 53 ayat (1) Undang-Undang tentang PTUN gugatan yang ada di PTUN diajukan oleh orang atau badan hukum perdata kecuali untuk sengketa kepegawaian. Padahal ini yang mengajukan adalah Badan/Pejabat pemerintahan yang mengeluarkan keputusan yang diduga mengandung unsur penyalahgunaan itu.

Untuk mengetahui objek permohonan pengujian unsur penyalahgunaan wewenang menurut Firna Novi Anggoro dapat dilihat dari ketentuan Pasal 3 diperkuat dengan Pasal 4 huruf (1) PERMA No. 4 Tahun 2015, objek permohonan pengujian unsur penyalahgunaan wewenang adalah Keputusan dan/atau Tindakan Pejabat Pemerintahan. ${ }^{14}$

14 Firna Novi Anggoro, Pengujian Unsur Penyalahgunaan Wewenang Terhadap Keputusan Dan/Atau Tindakan Pejabat Pemerintahan Oleh PTUN (Testing the Element Abuse of Authority toward Decision and/or Government Officials Act by Court Administrative), 10, 4, Jurnal Fiat Justitia, 2016, hlm., 638. 


\section{Kemungkinan Ketentuan Pasal 21 UU Administrasi Pemerintahan Mengatasi Kekhawatiran Pejabat Pemerintah}

Soal kekhawatiran pejabat dalam mengambil keputusan bisa berkait dengan soal keyakinan dan pemahaman yang dimilikinya. Dalam menjalankan tugas pemerintahan didasarkan kewenangan yang bisa menyangkut penggunaan keuangan negara yang harus dapat dipertanggungjawabkan. Sejumlah kasus muncul dimana pejabat pemerintah enggan mengambil keputusan yang mempunyai resiko untuk dimasukkan penyalahgunaan wewenang yang berujung pada tindak pidana korupsi. Hal tersebut mengakibatkan adanya penyerapan terhadap anggaran menjadi sedikit.

Gambaran mengenai hal itu dapat dilihat dalam beberapa kasus yang terjadi, misalnya Dinas Pekerjaan Umum dan Penataan Ruang (PUPR) Kota Depok baru mampu menyerap 40\% (APBD) 2018 padahal periode tutup buku tinggal tersisa sekitar dua bulan. Rendahnya penyerapan anggaran ini dikarenakan ketakutan para pejabat terhadap ancaman pidana. ${ }^{15}$ Hal senada juga disampaikan Anfujatin bahwa salah satu hal yang menyebabkan rendahnya penyerapan anggaran adalah lemahnya perlindungan hukum. Keputusan yang berkait dengan keuangan negara antara lain dalam pengadaan barang/jasa pemerintah. Kurangnya perlindungan hukum terhadap pelaku pengadaan. ${ }^{16}$ Kekhawatiran para pejabat pemerintah bukan faktor tunggal yang mengakibatkan rendahnya penyerapan anggaran, faktor lain yang menyebabkan penyerapan anggaran di daerah rendah adalah Lambatnya penetapan APBD, kualitas perencanaan yang tidak bagus, proyek-proyek yang diusulkan dalam APBD dan APBN masih membutuhkan penerjemahan. ${ }^{17}$

Menurut Edward James Sinaga minimnya penyerapan anggaran di kementerian, lembaga non kementerian, dan pemerintahan daerah kerap kali dituding sebagai indikator buruknya kinerja birokrasi. Penyerapan anggaran

15 https://mediaindonesia.com/read/detail/190673-serapan-anggaran-rendah-karena-pejabatpupr-depok-takut-dipidana, diakes 7 Juli 2019 Pukul 08:42.

16 Anfujatin, Analisis Faktor-Faktor Yang Menyebabkan Rendahnya Penyerapan Anggaran Belanja Pada Skpd Kabupaten Tuban, 14, 1, Jurnal Administrasi Publik, 2016, hlm.8.

17 https://www.beritasatu.com/nasional/303100/penyerapan-anggaran-rendah-inipenyebabnya, diakses 29 November 2019 Pukul 09:33. 
sendiri memang penting untuk mendorong terciptanya multiplier effect terhadap ekonomi, akan tetapi sejatinya kinerja birokrasi tidak bisa diukur semata-mata dengan penyerapan anggaran. ${ }^{18}$ Tingkat belanja pemerintah seringkali dijadikan barometer keberhasilan pemerintah dalam membuat perencanaan yang bermuara pada kesejahteraan masyarakat.

Pada waktu menjalankan pemerintahan sebagai Presiden dalam periode pertama, Joko Widodo merasa terpanggil untuk mencari penyelesaian rendahnya angka penyerapan anggaran karena para kepala daerah takut dipidanakan apabila melakukan kesalahan. Solusi yang muncul yaitu agar para gubernur tak perlu takut karena jika ada salah administrasi tak akan dijerat pidana. KPK menanggapi hal tersebut dan menganggap bahwa masalah kebijakan negara merupakan wewenang administratif. Dalam hal ada dugaan penyalahgunaan wewenang dari pejabat negara ini basisnya adalah otoritas dan ranah hukum administrasi negara, kecuali bila terbukti adanya mens rea (niat jahat) maupun kickback atau bribery maka hukum pidana dapat diterapkan untuk masalah ini. ${ }^{19}$

Pemberantasan korupsi kerap beririsan dengan upaya memajukan perekonomian negara. Hal ini menjadi dilema karena pejabat dianggap menjadi takut tersandera perkara korupsi manakala ingin menggunakan anggaran negara. Menarik yang disampaikan Jusuf Kalla bahwa ada perbedaan persepsi antara pemerintah dan penegak hukum dalam memandang pemberantasan korupsi. Kalau KPK, ukuran keberhasilannya kalau banyak yang ditangkap, sementara pemerintah ukuran keberhasilannya berkurang orang-orang ditangkap. Memberantas korupsi penting tapi akibatnya menghalangi triliunan anggaran tidak terserap, tetapi bila dibiarkan korupsi, anggaran ini habis dikorupsi. Jusuf Kalla mengaku tidak tahu bagaimana cara penyelesaiannya. ${ }^{20}$

18 Edward James Sinaga, Analisis Rendahnya Penyerapan Anggaran Kementerian/Lembaga (K/L) Dan Pemerintah Daerah, 5, 2, Jurnal Rechtsvinding Badan Pembinaan Hukum Nasional, 2016. hlm. 264.

19 https://news.detik.com/berita/3000017/ini-tanggapan-kpk-atas-keinginan-jokowi-agarkesalahan-administrasi-tidak-dipidana, diakses 8 September 2019 Pukul 18:16.

20 https://www.cnbcindonesia.com/news/20190808083259-4-90587/jk-efek-pemberantasankorupsi-pejabat-takut-ambil-keputusan, diakses 9 September 2019 Pukul 11:08. 
Ketika seorang pejabat pemerintah mengambil keputusan yang berkaitan dengan penggunaan anggaran, maka yang bersangkutan ada kemungkinan dinilai bersalah setelah dilakukan pengawasan oleh pejabat pengawas internal dan diduga melakukan penyalahgunaan wewenang. Pejabat yang membuat keputusan tersebut dapat mengajukan permohonan agar pengadilan menilai ada tidaknya penyalahgunaan wewenang tersebut. Apakah ini dapat membantu pejabat pemerintah untuk mengambil keputusan dan tidak khawatir lagi untuk dipersoalkan, merupakan sesuatu yang menarik.

Nancy Megawati, seorang Pejabat Daerah Pemerintah Kabupaten Purworejo yang dalam bekerja berkaitan dengan penggunaan anggaran mengatakan bahwa di dalam pelaksanaan jabatannya tidak mungkin untuk melakukan penyalahgunaan kewenangan. Beliau menilai bahwa ketentuan dalam Pasal 21 UU Administrasi Pemerintahan tersebut membantu dalam menjalankan tugas, sehingga terhindar dari kemungkinan penyalahgunaan wewenang. Terhadap fenomena banyak pejabat yang takut mengambil keputusan karena khawatir terkena kasus korupsi beliau berpendapat, bahwa sebagai seorang pemimpin harus tegas dan profesional dalam bekerja dan berani menolak apabila tidak sesuai dengan ketentuan dan aturan, profesional, mempunyai integritas yang tinggi, dan tidak terpengaruh KKN. ${ }^{21}$

Apa yang dikatakan oleh Nancy mencerminkan bagaimana pejabat sebagai pemegang kewenangan pemerintah menjadi salah satu kunci penting. Sikap dan tindakan dari pejabat dituntut untuk selalu selaras dengan norma hukum dan tatanan yang ada. Tidak mudah tergiur dan mempunyai integritas, serta ketegasan dari pejabat yang bersangkutan. Apabila hal tersebut dipegang dan dijalankan oleh pejabat, maka yang bersangkutan tidak sampai melakukan penyalahgunaan wewenang dalam pengambilan keputusan, sehingga tidak perlu menggunakan Pasal 21 UU Administrasi Pemerintahan untuk mengujinya. Tidak selalu mudah memang, karena kenyataanya tidak jarang aturannya tidak jelas atau belum ada, sementara keputusan itu harus diambil. Dalam hal seperti itu ruang diskresi

21 Wawancara dilakukan pada tanggal 5 Agustus tahun 2019 dan wawancara dilakukan dengan Nancy Megawati selaku Kepala Badan Kepegawaian Daerah Kabupaten Purworejo. 
terbuka, akan tetapi sekaligus di sinilah area abu-abu terbuka, yang sekalipun secara normatif ada asas-asas umum pemerintahan yang baik sebagai koridor.

Ahmad Kurniawan, mengatakan bahwa ketentuan dalam UU Administrasi Pemerintahan dan Perma Nomor 4 Tahun 2015, pengajuan permohonan pengujian dugaan penyalahgunaan wewenang setelah hasil pemeriksaan aparat pengawasan internal membantu pejabat pemerintah dalam melaksanakan tugasnya sehingga terhindar dari kemungkinan terjerat kasus penyalahgunaan wewenang dan korupsi. Terhadap fenomena banyak pejabat yang takut mengambil keputusan karena khawatir terkena kasus korupsi beliau menyatakan bahwa pejabat yang takut dilandasi karena sudah bekerja secara optimal namun masih dicari kesalahan oleh APH (Aparatur Penegak Hukum). Untuk itu solusi terbaik yang dapat digunakan untuk mengatasi persoalan tesebut adalah menerapkan permasalahan administrasi diselesaikan secara administratif. Untuk mengetahui persoalan administratif atau tidak maka diperlukan Aparatur Pengawas Internal Pemerintah sebagai penentunya. ${ }^{22}$

Apa yang disampaikan Ahmad Kurniawan mencerminkan bahwa ada harapan mestinya keputusan administrasi berhenti pada persoalan administrasi, demikian pula soal pengujiannya. Persoalan pidana baru dapat masuk apabila telah menyangkut unsur tindak pidana di dalamnya. Ketentuan Pasal 21 UU Administrasi Pemerintahan dapat membantu memberi kejelasan kepada pejabat pemerintah dalam mengambil keputusan agar tidak dikatakan melakukan penyalahgunaan wewenang. Batasan penyalahgunaan wewewenang sudah ditentukan dalam Pasal 17 dan Pasal 18 UU Administrasi Pemerintahan:

1. Badan dan/atau Pejabat Pemerintahan melampaui wewenang, yakni melampaui masa jabatan atau batas waktu berlakunya wewenang, melampaui batas wilayah berlakunya wewenang, dan/atau mengambil keputusan bertentangan dengan ketentuan peraturan perundangundangan.

2. Badan dan/atau Pejabat Pemerintahan mencampuradukkan wewenang, yakni di luar cakupan bidang atau materi wewenang yang diberikan, dan/atau bertentangan dengan tujuan wewenang yang diberikan.

22 Wawancara dilakukan pada tanggal 26 November tahun 2019 dan wawancara dilakukan dengan Achmad Kurniawan Kadir selaku Kepala Inspektorat Pemerintah Kabupaten Purworejo 
3. Badan dan/atau Pejabat Pemerintahan dikategorikan bertindak sewenang-wenang, yakni bila keputusan dan/atau tindakan yang dilakukan tanpa dasar kewenangan, dan/atau bertentangan dengan putusan pengadilan yang berkekuatan hukum tetap.

Pejabat pemerintah tidak bisa dikatakan melakukan penyalahgunaan wewenang sepanjang tidak melakukan hal-hal tersebut. Dengan ketentuan Pasal 21 UU Administrasi Pemerintahan maka dapat digunakan untuk menguji dan memastikan ada tidaknya penyalahgunaan wewenang bagi pejabat pemerintah dengan ukuran yang begitu agak terperinci. Apabila pejabat pemerintah merasa bahwa keputusan yang dilakukan tersebut tidak mengandung satupun unsurunsur tersebut, mestinya tidak perlu khawatir terjerat pada persoalan penyalahgunaan wewenang. Pejabat tersebut tidak perlu enggan untuk mengambil keputusan.

Dalam Pasal 20 ayat (2) UU Administrasi Pemerintahan menentukan bahwa:

"Hasil pengawasan aparat pengawasan interen pemerintah sebagaimana dimaksud pada ayat (1) berupa:

a. tidak terdapat kesalahan;

b. terdapat kesalahan administratif; atau

c. terdapat kesalahan administratif yang menimbulkan kerugian keuangan negara."

Bila ternyata hasil pengawasan aparat internal pemerintah berupa terdapat kesalahan administratif, maka dilakukan tindak lanjut dalam bentuk penyempurnaan administrasi sesuai dengan ketentuan peraturan perundangundangan. Jika hasil pengawasan aparat intern pemerintah berupa terdapat kesalahan administratif yang menimbulkan kerugian keuangan negara, maka dilakukan pengembalian kerugian keuangan negara paling lama 10 (sepuluh) hari kerja terhitung sejak diputuskan dan diterbitkannya hasil pengawasan. Pengembalian kerugian negara dibebankan kepada Badan Pemerintahan, apabila kesalahan administratif terjadi bukan karena adanya unsur penyalahgunaan Wewenang. Pengembalian kerugian negara dibebankan kepada 
Pejabat Pemerintahan, apabila kesalahan administratif terjadi karena adanya unsur penyalahgunaan Wewenang.

Untuk memastikan ada tidaknya penyalahgunaan wewenang dalam keputusan pejabat pemerintah tersebut, maka Pasal 21 membuka kesempatan kepada pejabat tersebut membawanya ke Pengadilan Tata Usaha Negara, untuk dilakukan pengujian. Dengan adanya putusan berupa penetapan pengadilan tersebut akan membawa konsekuensi mengenai siapa yang bertanggung jawab untuk mengembalikan kerugian negara, terhadap kesalahan administratif yang menimbulkan kerugian bagi negara. Bila ada kesalahan administratif bukan karena adanya unsur penyalahgunaan Wewenang, pengembalian kerugian negara dibebankan kepada Badan Pemerintahan. Bila kesalahan administratif terjadi karena adanya unsur penyalahgunaan wewenang, maka pengembalian kerugian negara dibebankan kepada Pejabat Pemerintahan. Dengan demikian jelas sekali bahwa ini merupakan batas persoalan dalam Hukum Administrasi, bukan soal pidana.

Sejalan dengan persoalan yang diangkat dalam tulisan ini, maka apakah dapat membantu pejabat pemerintah untuk tidak takut melakukan pengambilan keputusan, tentu dapat membantu sebatas aspek administratif, bukan persoalan pidananya, termasuk soal korupsinya. Apabila tidak ada penyalahgunaan wewenang maka akibat dari kesalahan administratif itu menjadi tanggung jawab jabatanya, maka lembaganya yang mengembalikan kerugian negara. Bila ada penyalahgunaan wewenang maka akibat dari kesalahan administratif itu menjadi tanggung jawab pribadi, karena sebagai pejabat yang menyalahgunakan kewenangan sehingga dialah yang harus mengembalikan kerugian negara. Pengujian berdasar Pasal 21 UU Administrasi Pemerintahan tersebut juga dapat membantu pejabat pemerintah dalam memastikan dirinya untuk mengambil keputusan, bila tafsir yang dipakai dalam tindak pidana korupsi mengenai penyalahgunaan wewenang adalah sama dengan yang ada di UU Administrasi Pemerintahan. Maksudnya manakala sudah diuji melalui Pasal 21 UU Administrasi Pemerintahan, maka putusan hakim PTUN itu yang dipakai, termasuk kalau ada yang mempersoalkan korupsinya. Hal tersebut sebenarnya 
juga memungkinkan, mengingat baik dalam KUHP maupun UU Pemberantarasan Tipikor tidak ada kejelasan mengenai apa yang dimaksud dengan penyalahgunaan wewenang itu. Bahkan dalam penanganan korupsi penafsiran dengan meminjam ketentuan dalam UU Administrasi Pemerintahan juga dipakai di dalam praktek. Jika mekanisme dan ukuran tersebut dapat memberikan keyakinan bahwa tindakan dan keputusan yang dibuatnya benar, maka tentu akan membantu pejabat pemerintah dalam mengambil keputusan.

\section{Pengaruh Ketentuan Pasal 21 Undang-Undang Nomor 30 Tahun 2014 Terhadap Penyelesaian Kasus Korupsi}

Seringkali penyalahgunaan wewenang dikaitkan dengan korupsi, yang di dalamnya terkandung unsur adanya niat jahat sebagai salah satu unsur penting selain unsur lainya. Niat jahat ini berkait dengan sikap batin (mens rea) yang sebenarnya dapat dikatakan berimpit dengan tujuan penggunaan wewenang. Keduanya ada di dalam diri pengambil keputusan(subjektif). Apakah di dalam pengambilan keputusan mempunyai tujuan yang sesuai dengan tujuan pemberian kewenangan atau sebaliknya ada niat jahat dari pejabat tersebut, maka sejatinya ada di dalam hati dan pikiran pejabat tersebut.

UU Administrasi Pemerintahan telah mengatur mengenai adanya larangan penyalahgunaan wewenang, yaitu dalam Pasal 17 dan dijelaskan kembali secara detail dalam Pasal 18 tentang tindak penyalahgunaan wewenang tersebut. Dalam Pasal 3 UU Pemberantasan Tipikor ditentukan:

"Setiap orang yang dengan tujuan menguntungkan diri sendiri atau orang lain atau suatu korporasi, menyalahgunakan kewenangan, kesempatan atau sarana yang ada padanya karena jabatan atau kedudukan yang dapat merugikan keuangan negara atau perekonomian negara, dipidana dengan pidana."

Penjelasan Pasal 3 UU Pemberantasan Tipikor tidak menjelaskan mengenai makna dari "menyalahgunakan kewenangan." Penjelasan pasal tersebut hanya menjelaskan kata "dapat" sebelum frasa "merugikan keuangan atau perekonomian negara." 
Diakui oleh Indriyanto Seno Adji pengertian penyalahgunaan wewenang atau menyalahgunakan kewenangan tidak ditemukan dalam KUHP maupun di dalam UU Pemberantasan Tipikor secara expressis verbis, dan dikemukakan bahwa pengertian penyalahgunaan "menyalahgunakan wewenang" dalam hukum pidana korupsi tidak memiliki pengertian yang eksplisitas sifatnya. ${ }^{23}$

Senada dengan Indriyanto Seno Adji, Adami Chazawi mengemukakan mengenai apa yang dimaksud dengan menyalahgunakan kewenangan tidak ada keterangan lebih lanjut dalam undang-undang, ${ }^{24}$ atau dapat dikatakan Undangundang dalam keadaan diam (silentio of de wet).

Dalam pembentukan peraturan perundang-undangan, pembentuk undangundang adakalanya menganggap bahwa suatu peristilahan itu sudah cukup jelas, karena sudah sangat sering dipakai dalam praktek, meskipun pihak yang menjalankan undang-undang, yang menegakkan undang-undang dan publik belum tentu menangkapnya sebagai sesuatu yang benar-benar jelas. Penjelasan berfungsi sebagai tafsir resmi pembentuk peraturan perundang-undangan atas norma tertentu dalam batang tubuh. Oleh karena itu, penjelasan hanya memuat uraian terhadap kata, frasa, kalimat atau padanan kata/istilah asing dalam norma yang dapat disertai dengan contoh.

Parameter yang membatasi gerak bebas kewenangan aparatur negara (discretionary power) dalam perspektif hukum administrasi negara adalah detournament de povouir (penyalahgunaan wewenang) dan abus de droit (sewenang-wenang). Sementara itu, dalam kriteria perspektif hukum pidana yang membatasi gerak bebas kewenangan aparatur negara berupa unsur wederrechtlijkheid dan "menyalahgunakan wewenang". Permasalahan area hukum pidana tidak sesulit apabila dilakukan pembedaan sebagai titik singgung (grey area) antara hukum administrasi negara dengan hukum pidana, khususnya tindak pidana korupsi. ${ }^{25}$

23 Indriyanto Seno Adji, Korupsi dan Pembalikan Beban Pembuktian, Kantor Pengacara dan Konsultan Hukum, Jakarta, 2006, hlm. 12.

24 Adami Chazawi, Hukum Pidana Korupsi Di Indonesia (Edisi Revisi) PT RajaGrafindo, Jakarta, 2016, hlm. 60.

25 Indriyanto Seno Adji, Supra note 23, hlm. 10 
Lahirnya ketentuan dalam UU Administrasi Pemerintahan tersebut telah menimbulkan perbedaan pendapat di antara para ahli hukum, khususnya ahli Hukum Administrasi Negara dan ahli Hukum Pidana berkenaan dengan keberlakuan ketentuan dimaksud dan pengaruhnya terhadap kewenangan Peradilan Tipikor. Guntur Hamzah, Guru Besar Hukum Administrasi Universitas Hasanuddin, menyatakan keberadaan UU Administrasi Pemerintahan akan memperkuat dan menambah daya dobrak upaya pemberantasan korupsi, sebab tindakan penyalahgunaan wewenang ini sudah dicegah dalam birokrasi pemerintahan melalui Aparatur Pengawasan Intern Pemerintah (APIP). Dengan adanya APIP, adanya dugaan penyalahgunaan wewenang dapat dideteksi sejak dini sebagai upaya preventif (pencegahan). ${ }^{26}$

Menurut Estiningtyas Diana Mandagi adanya ketentuan Pasal 21 UU Administrasi Pemerintahan diharapkan dapat mencegah praktik korupsi yang dilakukan oleh pejabat pemerintahan. Praktek KKN tidak tergantung pada sistem semata tetapi juga kepatuhan pejabat yang bersangkutan. Sesuai dengan ketentuan dalam UU Administrasi Pemerintahan dan Peraturan Ketua Mahkamah Agung Nomor 4 Tahun 2015, pengajuan permohonan pengujian dugaan penyalahgunaan wewenang yang dilakukan setelah hasil pemeriksaan aparat pengawasan internal tidak menyebabkan terjadinya tumpang tindih kewenangan mengadili antara PTUN dan Peradilan Umum. ${ }^{27}$ Ditambahkan olehnya bahwa ketentuan tersebut sudah bersesuaian sebab tidak boleh terjadi benturan norma.

Pendapat senada disampaikan oleh Riyadi Sunindyo, bahwa adanya Undang-Undang dan Peraturan Mahkamah Agung tersebut penanganan perkara antara peradilan tidaklah menjadi tumpang tindih. Dalam hal ini mempertimbangkan tentang unsur penyalahgunaan wewenang antara produk TUN yang sifatnya administratif dengan Pengadilan tipikor yang memandang dalam konteks yang berkaitan dengan unsur-unsur lain dalam Pasal 2 dan Pasal 3 UU Pemberantasan Tipikor. Bisa terjadi di Pengadilan TUN yang bersangkutan

26 https://www.hukumonline.com/berita/baca/lt5514fdcf7f91b/uu-administrasipemerintahan-trigger-berantas-korupsi/, diakses 19 Februari 2020 pukul 22.15.

27 Wawancara dilakukan pada tanggal 5 Agustus 2019 wawancara dilakukan terhadap Estiningtyas Diana Mandagi, selaku Hakim Pada Pengadilan Tata Usaha Negara Yogyakarta. 
memutuskan bahwa keputusan pejabat itu tidak menyalahgunakan wewenang tetapi dari sisi UU Tipikor ada penyalahgunaan wewenang. Sebagai contoh yang terjadi antara PTUN Medan dan Pengadilan Tindak Pidana Korupsi Medan. Hal tersebut disebabkan karena yang diajukan ke Pengadilan TUN bentuknya Permohonan yang menghasilkan Penetapan bukan putusan (voluntair jurisdiction bukan Contentiosa jurisdiction). Undang-Undang tentang Administrasi Pemerintahan dan Peraturan Mahkamah Agung itu sendiri tidak menjadi penghalang atau perintang bagi penegakan hukum terhadap tipikor, karena banyak juga diskresi yang mengandung tipikor. ${ }^{28}$

Pasal 3 UU Pemberantasan Tipikor menentukan "Setiap orang yang dengan tujuan menguntungkan diri sendiri atau orang lain atau suatu korporasi, menyalahgunakan kewenangan, kesempatan atau sarana yang ada padanya karena jabatan atau kedudukan yang dapat merugikan keuangan negara atau perekonomian negara."

Agak berbeda dengan unsur tindak pidana korupsi yang diatur dalam Pasal 2 ayat (1), dalam Pasal 3 ini ditentukan bahwa tindakan yang bertujuan menguntungkan diri sendiri, orang lain, atau korporasi, menyalahgunakan kewenangan, kesempatan atau sarana yang ada padanya karena jabatan atau kedudukan dan dapat menimbulkan kerugian pada negara atau perekonomian negara masuk dalam kualifikasi tindak pidana korupsi. Dalam hal ini penyalahgunaan kewenangan sudah menjadi salah satu unsur tindak pidana yang memang disebutkan secara jelas di dalamnya.

Dalam suatu paparan Pusat Penerangan Kejaksaan Agung Republik Indonesia yang dimuat di laman resmi Kejaksaan Agung Republik Indonesia dibahas mengenai hal tersebut. Sesuai dengan Pasal 3 UU Pemberantasan Tipikor, penyalahgunaan wewenang adalah "Setiap orang yang bertujuan menguntungkan diri sendiri ataupun orang lain atau suatu korporasi, apabila Ia menyalahgunakan wewenang, kesempatan atau sarana yang melekat padanya karena jabatan atau

28 Wawancara dilakukan pada tanggal 6 Agustus 2019 wawancara dilakukan terhadap Riyadi Sunindyo, selaku Hakim pada Pengadilan di lingkungan Peradilan Umum. 
kedudukannya, dan perbuatannya itu dapat merugikan negara atau perekonomian negara dijatuhi pidana".

Tabel 1: Perbedaan arti penyalahgunaan wewenang antara Hukum Administrasi dan UU Tindak Pidana Korupsi

\begin{tabular}{llll}
\hline $\begin{array}{l}\text { Penyalahgunaan Wewenang Menurut Hukum } \\
\text { Administrasi }\end{array}$ & $\begin{array}{l}\text { Penyalahgunaan Wewenang Menurut } \\
\text { UU Tindak Pidana Korupsi }\end{array}$ & \\
\hline $\begin{array}{l}\text { Melakukan tindakan yang bertentangan dengan } \\
\text { kepentingan umum }\end{array}$ & $\begin{array}{l}\text { Melanggar aturan tertulis yang menjadi } \\
\text { dasar kewenangan }\end{array}$ & \\
\hline $\begin{array}{l}\text { Menyimpang dari tujuan kewenangan yang } \\
\text { diberikan oleh UU atau peraturan lainnya }\end{array}$ & $\begin{array}{l}\text { Memiliki maksud yang menyimpang } \\
\text { walaupun perbuatan sudah sesuai dengan } \\
\text { peraturan }\end{array}$ & \\
\hline Menyalahgunakan suatu prosedur & Berpotensi merugikan negara \\
\hline
\end{tabular}

Sumber: Laman Kejaksaan Agung RI $^{29}$

Uraian dalam tabel tersebut memberikan gambaran bahwa apa yang digunakan dalam Hukum Administrasi tidak sama dengan apa yang digunakan dalam Hukum Pidana dalam melihat suatu "penyalahgunaan wewenang." parameter yang digunakan memang agak berbeda.

Unsur penyalahgunaan kewenangan Pasal 3 UU Pemberantasan Tipikor bersifat alternatif, karena selain penyalahgunaan wewenang juga kesempatan dan sarana yang ada padanya karena jabatan adalah unsur tindak pidana korupsi. Penyalahgunaan kewenangan pada dasarnya merupakan perbuatan melawan hukum (dalam artian tindak pidana) harus disertai dengan adanya mens rea (berniat jahat). Bentuk konkret mens rea adanya actus reus berupa fraud, conflict of interest, dan illegality, sehingga merupakan tindak pidana kejahatan. Sedangkan akibat dari penyalahgunaan wewenang dan sewenang-wenang dalam ranah HAN adalah mengakibatkan keputusan pejabat tidak sah dan dapat dibatalkan. ${ }^{30}$

Berdasarkan interpretasi moderen yang menekankan arti kata-kata dalam konteks dimana kata itu digunakan A'an Efendy mengemukakan pendapatnya. Analisis konteks mengenai bahasa terhadap UU Pemberantasan Tipikor menggunakan prinsip yang relevan yaitu prinsip the noscitur a sociis,

29 http://www.kejaksaan.go.id/uplimg/Peran\%20PNS\%20dalam\%20membangun\% 20budaya.ppt. Diunduh tanggal 29 November 2019.

30 Andi Nirwanto, Arah Pemberantasan Korupsi Ke Depan (Pasca undang-Undang Administrasi Pemerintahan). Makalah yang disampaikan pada Seminar Nasional HUT IKAHI Ke 62 di Hotel Mercure Ancol Jakarta pada tanggal 26 Maret 2015 
prinsip ejusdem generis, prinsip the expressio unius exclusio alterius, dan prinsip pari materia. Berdasarkan analisis konteks mengenai bahasa dengan sejumlah prinsipnya dapat dipetik poin penting, bahwa makna menyalahgunakan wewenang dalam Pasal 3 harus ditafsirkan dalam konteks tindak pidana korupsi tidak dalam konteks lainnya. Jadi, menyalahgunakan wewenang dalam Pasal 3 UU Pemberantasan Tipikor harus dimaknai dalam ruang lingkup tindak pidana korupsi bukan menyalahgunakan wewenang yang ada dalam wilayah hukum administrasi. ${ }^{31}$

Menurut Suryo Hendratmoko, sebuah perbuatan melanggar hukum syaratnya apabila sudah ada mens rea/niat jahat sehingga berniat mengantongi uang negara, bukan lalai karena resiko pekerjaan. Dia berpendapat bahwa semua perbuatan melanggar hukum oleh badan/pejabat pemerintah sudah menjadi kewenangan PTUN bukan PN untuk menanganinya. Menurutnya mesti kembali pada pengertian tindak pidana korupsi itu sendiri, dimana 'harus ada mens reanya'/niat jahat atau perbuatan yang tentunya disengaja, yang mana seseorang telah melakukan perbuatan dengan maksud menguntungkan diri sendiri atau orang lain. Jadi seseorang yang akan dijadikan tersangka sebagai pelaku tindak pidana korupsi harus memenuhi itu. Baik juga bagi setiap orang yang menyalahgunakan jabatan/kewenangan dengan maksud (sama) sehingga merugikan keuangan negara. Menurut Suryo Hendratmoko mengenai harus terlebih dahulu ada pemeriksaan aparat pengawasan internal sepertinya diselesaikan terlebih dahulu lewat internal pemerintah daerah/pusat karena barangkali masih merupakan bentuk kelalaian dan bukanlah faktor kesengajaan yang memenuhi delik Pasal 2 dan Pasal 3 Undang-Undang tentang Pemberantasan Tindak pidana korupsi. Berkaitan dengan Peraturan Mahkamah Agung nomor 4 Tahun 2015 itu dimaksudkan pelanggaran yang masih bersifat administrasi dan sepertinya untuk keputusan/kebijakan dalam bidang hukum publik bukan

31 A'an Efendy, Interpretasi Modern Makna Menyalahgunakan Wewenang Dalam Tindak Pidana Korupsi, Kajian Putusan Nomor 977 K/Pid/2004, Jurnal Yudisial Vol. 12 No. 3 Desember 2019, 337-338. 
perbuatan pemerintah sebagai subyek hukum perdata. ${ }^{32}$ Sebagaimana diketahui bahwa ada sejumlah unsur tindak pidana korupsi. Penyalahgunaan wewenang merupakan salah satu unsurnya, demikian juga unsur melawan hukum. Dua hal tersebut tidak sama persis. Pasal 21 UU Administrasi Pemerintahan lebih mengatur mengenai persoalan dugaan penyalahgunaan wewenang, bukan tindakan melawan hukum yang dilakukan oleh pemerintah.

Hal yang disampaikan Suryo Hendratmoko tersebut menarik bila dihubungkan dengan Pendapat Philipus M Hadjon. Menurut Philipus M. Hadjon, untuk mengukur apakah telah terjadi penyalahgunaan wewenang haruslah dibuktikan secara faktual bahwa pejabat telah menggunakan wewenangnya untuk tujuan lain. Terjadinya penyalahgunaan wewenang bukanlah karena kealpaan. Penyalahgunaan wewenang dilakukan secara sadar yaitu mengalihkan tujuan yang telah diberikan kepada wewenang itu yang didasarkan atas kepentingan pribadi, baik untuk kepentingan dirinya sendiri ataupun untuk orang lain. ${ }^{33}$ Verklarend Woordenboek Openbaar Bestuur sebagaimana dikutip oleh Philipus M Hadjon menyampaikan bahwa penyalahgunaan wewenang (detournement de pouvoir) adalah penggunaan wewenang tidak sebagaimana mestinya. Dalam hal ini pejabat menggunakan wewenangnya untuk tujuan lain yang menyimpang dari tujuan yang telah diberikan kepada wewenang itu. ${ }^{34}$ Oleh karena itu sebenarnya kehendak dari pembuat keputusan menjadi sangat penting, karena di situ menyangkut tujuan.

Trisoko Sugeng Sulistyo, seorang hakim Pengadilan TUN mengatakan bahwa sesuai ketentuan dalam UU Administrasi Pemerintahan dan Peraturan Ketua Mahkamah Agung Nomor 4 Tahun 2015 pengajuan permohonan pengujian dugaan penyalahgunaan wewenang setelah hasil pemeriksaan aparatur pengawasan internal memang bisa menimbulkan tumpang tindih kewenangan mengadili antara Pengadilan TUN dan Pengadilan Negeri, akan tetapi hakim dapat menyelesaikannya dengan preferensi hukum. Menurutnya ketentuan dalam UU

32 Suryo Hendratmoko, Hakim Pengadilan Negeri, wawancara pribadi tanggal 25 September 2019.

33 Philipus M. Hadjon et.al. Supra note 5. hlm. 22.

34 Philipus M. Hadjon et.al. Supra note 10. hlm. 25-26. 
Administrasi Pemerintahan dan Peraturan Ketua Mahkamah Agung tersebut secara garis besar sudah tepat, walau ada beberapa permasalahan, sekaligus menanti perbaikan-perbaikan peraturan. Peraturan ini merupakan salah satu metode untuk mencegah praktik korupsi. ${ }^{35}$

Krisna Harahap mempunyai pendapat yang berbeda dengan Trisoko, Hakim Agung pada Mahkamah Agung ini menyatakan UU Administrasi Pemerintahan menghambat upaya pemberantasan Tipikor karena ketentuanketentuan yang tertuang dalam UU Administrasi Pemerintahan nyata-nyata tidak selaras dengan UU Tipikor seperti Pasal 3 UU ini mengatur bagaimana "setiap orang yang menyalahgunakan kewenangan, kesempatan atau sarana yang ada padanya karena jabatan atau kedudukan yang dapat merugikan keuangan negara atau perekonomian Negara. Setiap orang yang memenuhi unsur-unsur delik yang diatur dalam Pasal 3 (bukan hanya Pegawai Negeri) terancam pidana penjara 1-20 tahun. UU Administrasi Pemerintahan menghambat upaya pemberantasan korupsi. ${ }^{36}$

Pendapat yang senada juga disampaikan oleh Erwin Natosmal Oemar, peneliti pada Indonesia Legal Roundtable (ILR). Menurutnya UU Administrasi Pemerintahan dinilai mengkudeta upaya pemberantasan korupsi. Sebab, dalam menjerat penyalahgunaan wewenang pejabat negara yang merugikan negara, penyidik harus memutar terlebih dahulu ke Pengadilan Tata Usaha Negara (PTUN). ${ }^{37}$

Beberapa pendapat yang disampaikan tersebut tentu menarik. Untuk penanganan kasus korupsi Mahkamah Agung pernah mengambil konsep hukum administrasi. Dalam Putusan Nomor 977 K/Pid/2004 dalam perkara dengan terdakwa HHS, Mahkamah Agung mengambil konsep dalam hukum administrasi untuk menafsirkan pengertian penyalahgunaan wewenang dalam memutus perkara tindak pidana korupsi. Hal tersebut dilakukan dengan memberikan

35 Trisoko Sugeng Sulistyo, Hakim Pengadilan TUN, wawancara pribadi tanggal 20 Desember 2019.

36 Krisna Harahap, https://news.detik.com/berita/d-2873765/uu-administrasi-pemerintahandinilai-mengudeta-pemberantasan-korupsi, diakses 28 Februari 2020.

37 Erwin Natosmal Oemar, https://news.detik.com/berita/d-2873765/uu-administrasipemerintahan-dinilai-mengudeta-pemberantasan-korupsi, diakses 19 Februari 2020. 
makna menyalahgunakan wewenang dalam tindak pidana korupsi dengan cara mengambil alih konsep penyalahgunaan wewenang dalam hukum administrasi. Pada bagian menimbang dari putusan tersebut pada halaman 196 sampai dengan halaman 199, Mahkamah menyatakan sebagai berikut: Kesimpulannya dikatakan bahwa mengenai perkataan yang sama, hukum pidana mempunyai otonomi untuk memberikan pengertian yang berbeda dengan pengertian yang terdapat dalam cabang ilmu hukum lainnya, akan tetapi jika hukum pidana tidak menentukan lain, maka dipergunakan pengertian yang terdapat dalam cabang hukum lainnya. Dengan demikian, apabila pengertian "menyalahgunakan kewenangan" tidak ditemukan eksplisitasnya dalam hukum pidana, maka hukum pidana dapat menggunakan pengertian dan kata yang sama yang terdapat atau berasal dari cabang hukum lainnya. Pada waktu itu memang belum lahir UU Administrasi Pemerintahan.

Hal serupa juga dapat dilihat dalam Putusan Mahkamah Agung Republik Indonesia (MARI) Nomor: 14/Pid.Sus /2012/PN.AB. dengan Terdakwa Edi Tri Sukmono alias Edi dan Putusan MARI Nomor: 03/PID.SUS/TPK/ 2013/PN.PBR, dengan Terdakwa Amril Daud. Dalam putusan tersebut untuk menjelaskan unsur "menyalahgunakan kewenangan" yang terdapat dalam ketentuan Pasal 3 UU Pemberantasan Tipikor diterapkan penafsiran ekstensif menggunakan pendekatan doktrin otonomi hukum pidana.

Presiden Jokowi melalui kebijakan yang dikeluarkannya telah menginstruksikan kepada Jaksa Agung dan Kapolri agar mendahulukan proses administrasi pemerintahan sesuai ketentuan UU Administrasi Pemerintahan sebelum melakukan penyidikan atas laporan masyarakat berkenaan dengan dugaan penyalahgunaan wewenang, khususnya dalam pelaksanaan Proyek Strategis Nasional yang dinilai sangat penting. ${ }^{38}$ Kebijakan dari Presiden tersebut menggambarkan bahwa pemerintah menghendaki adanya penanganan kasus penyalahgunaan wewenang mengedepankan aspek hukum administrasi, penanganan pidana sebagai ultimum remidium, bukan primum remedium.

38 Bagian Keenam angka 1 Instruksi Presiden RI Nomor 1 Tahun 2016 tentang Percepatan Pelaksanaan Proyek Strategis Nasional. 
Pengujian yang dilakukan oleh PTUN berdasar Pasal 21 UU Administrasi Pemerintahan terhadap dugaan penyalahgunaan wewenang oleh Pejabat Pemerintahan merupakan pengujian yang lebih menekankan aspek administratifnya. Parameter yang dipakai agak berbeda dengan yang dipakai dalam kasus korupsi. Oleh karena itu pengujian ini lebih membantu di dalam penyelesaian persoalan aspek hukum administrasinya. Salah satu yang penting dalam pengujian ini adalah soal tujuan dari si pelaku yakni Pejabat pemerintahan yang mengambil keputusan. Oleh karena itu mestinya juga dapat dilakukan pengujian dengan baik terhadap niat dari subjeknya, karena kalau akan digunakan dalam penanganan kasus korupsi aspek niat jahat yang menjadi kehendak dari pelaku itu menjadi hal yang penting. Apabila hal tersebut diuji maka dapat membantu dalam penanganan kasus korupsi, terutama terhadap dugaan penyalahgunaan wewenang. Unsur lain dari tindak pidana korupsi tentu masih bisa dilakukan pengujian oleh pengadilan, misalnya oleh pengadilan tipikor.

\section{Penutup}

Ketentuan Pasal 21 UU Administrasi Pemerintahan Tersebut dapat digunakan untuk membantu memberikan kepastian sejak awal hingga tidak sampai pada tindak pidana korupsi. Parameter yang digunakan dalam pengujian oleh Pengadilan TUN begitu jelas dan agak berbeda dengan yang digunakan dalam Perkara korupsi. Untuk itu pengujian tersebut lebih membantu bagi penyelesaian persoalan administrasinya. Pengujian ada tidaknya penyalahgunaan wewenang keputusan pejabat pemerintahan yang dilakukan oleh PTUN berdasar Pasal 21 UU Administrasi Pemerintahan dengan proses lebih sederhana, ukuran yang jelas dan jangka waktu yang dibatasi, sehingga dapat membantu memberikan kepastian ada tidaknya penyalahgunaan wewenang baik dari materi maupun waktu penyelesaian di PTUN. Oleh karena itu sejalan dengan persoalan yang diangkat dalam tulisan ini, maka apakah dapat membantu pejabat pemerintah untuk tidak takut melakukan pengambilan keputusan, tentu dapat membantu sebatas aspek administratif, bukan persoalan pidananya, termasuk soal korupsinya. 
Ketentuan dalam Pasal 21 UU Administrasi Pemerintahan dapat memberikan kepastian mengenai ada tidaknya penyalahgunaan wewenang pejabat pemerintahan dalam mengambil keputusan dari aspek administratifnya, sehingga tidak menyangkut kasus korupsi. Seandainya dalam penanganan kasus korupsi hakim dibenarkan mengambil ajaran dalam hukum administrasi mengenai penyalahgunaan wewenang, maka tentu ini akan membantu hakim tersebut dalam menangani kasus korupsi, khususnya bila pengujian berdasarkan Pasal 21 UU Administrasi Pemerintahan itu dilakukan sebelum penanganan kasus pidananya.

\section{Daftar Pustaka}

\section{Buku:}

Adami Chazawi, Hukum Pidana Korupsi Di Indonesia (Edisi Revisi) PT Raja Grafindo, Jakarta, 2016.

Henry Campbell Black, M. A., Black's Law Dictionary, St. Paul, Minn. West Publishing Co. 1990. $6^{\text {th }}$ Edition.

Indriyanto Seno Adji, Korupsi, Kebijakan Aparatur Negara dan Hukum Pidana. Diadit Media, Jakarta, 2009.

Indriyanto Seno Adji, Korupsi dan Pembalikan Beban Pembuktian, Kantor Pengacara dan Konsultan Hukum, Jakarta, 2006.

Marsono, Susunan Dalam Satu Naskah UUD 1945 dengan Perubahanperubahannya 1999-2002, Eko Jaya, Jakarta, 2002.

Nur Basuki Minarno Penyalahgunaan Wewenang dalam Pengelolaan Keuangan Daerah yang Berimplikasi Tindak Pidana Korupsi, Laksbang Mediatama, Surabaya, 2011.

Philipus M Hadjon et.al. Hukum Administrasi dan Tindak Pidana Korupsi, Gadjah Mada University Press, Yogyakarta, 2011.

Hukum Administrasi dan Good Governance, Penerbit Universitas Trisakti, Jakarta. 2012.

Philipus M Hadjon, Tatiek Sri Djalmiati, Hukum Administrasi dan Tindak Pidana Korupsi, Gadjahmada University Press, Yogyakarta, 2011. 
Stroink, F.A.M. dan J.G. Steenbeek, Inleiding in het StaatsenAdministrastief Rech. Alphen aan den Rijn: Samsom H.D. TjeenkWilink, 1985.

Supandi, Hukum Peradilan Tata Usaha Negara, Alumni, Bandung, 2016.

\section{Jurnal:}

A'an Efendy, Interpretasi Modern Makna Menyalahgunakan Wewenang Dalam Tindak Pidana Korupsi, Kajian Putusan Nomor 977 K/Pid/2004. Jurnal Yudisial Vol. 12 No. 3 Desember 2019.

Anfujatin, Analisis Faktor-Faktor Yang Menyebabkan Rendahnya Penyerapan Anggaran Belanja Pada Skpd Kabupaten Tuban, Jurnal Administrasi Publik, Vol. 14, No. 1.Juni 2016,

Edward James Sinaga, Analisis Rendahnya Penyerapan Anggaran Kementerian/Lembaga (K/L) Dan Pemerintah Daerah, Jurnal Rechtsvinding Badan Pembinaan Hukum Nasional, Volume 5 Nomor 2, Agustus 2016.

Firna Novi Anggoro, Pengujian Unsur Penyalahgunaan Wewenang Terhadap Keputusan Dan/Atau Tindakan Pejabat Pemerintahan Oleh PTUN (Testing the Element Abuse of Authority toward Decision and/or Government Officials Act by Court Administrative), Jurnal Fiat Justitia, Universitas Lampung, Vol.10.edisi.4, Des 2016.

Philipus M Hadjon, Tentang Wewenang, http://journal.unair.ac.id/downloadfullpapers-yuridika557e071ab6full.pdf.

\section{Makalah:}

Andi Nirwanto, Arah Pemberantasan Korupsi Ke Depan (Pasca undang-Undang Administrasi Pemerintahan). Makalah yang disampaikan pada Seminar Nasional HUT IKAHI Ke 62 di Hotel Mercure Ancol Jakarta pada tanggal 26 Maret 2015

\section{Internet}

http://www.kejaksaan.go.id/uplimg/Peran\%20PNS\%20dalam\%20membangun\% 20budaya.ppt. Diunduh tanggal 29 November 2019.

https://mediaindonesia.com/read/detail/190673-serapan-anggaran-rendahkarena-pejabat-pupr-depok-takut-dipidana, diunduh tanggal 7 Juli 2019.

https://news.detik.com/berita/3000017/ini-tanggapan-kpk-atas-keinginanjokowi-agar-kesalahan-administrasi-tidak-dipidana, diakses 8 September 2019.

https://www.beritasatu.com/nasional/303100/penyerapan-anggaran-rendahini-penyebabnya. Diunduh tanggal 29 November 2019

https://www.cnbcindonesia.com/news/20190808083259-4-90587/jk-efekpemberantasan-korupsi-pejabat-takut-ambil-keputusan, diakses 9 September 2019

Erwin Natosmal Oemar, https://news.detik.com/berita/d-2873765/uuadministrasi-pemerintahan-dinilai-mengudeta-pemberantasan-korupsi, diakses tanggal 19 Februari 2020. 
Krisna Harahap, https://news.detik.com/berita/d-2873765/uu-administrasipemerintahan-dinilai-mengudeta-pemberantasan-korupsi, diakses tanggal 28 Februari 2020.

UU Administrasi Pemerintahan "Trigger" Berantas Korupsi, https://www.hukumonline.com/berita/baca/lt5514fdcf7f91b/uuadministrasi-pemerintahan-trigger-berantas-korupsi/, diakses tanggal 19 Februari 2020.

\section{Wawancara:}

Achmad Kurniawan Kadir, Kepala Inspektorat Pemerintah Kabupaten Purworejo, wawancara pribadi tanggal 26 November 2019.

Estiningtyas Diana Mandagi. Hakim Pada Pengadilan Tata Usaha Negara Yogyakarta, wawancara pribadi tanggal 5 Agustus 2019.

Nancy Megawati, Kepala Badan Kepegawaian Daerah Pemda Purworejo, wawancara pribadi tanggal 5 Agustus 2019.

Riyadi Sunindyo, Hakim pada Pengadilan di lingkungan Peradilan Umum, wawancara pribadi tanggal 6 Agustus 2019.

Suryo Hendratmoko,.Hakim Pengadilan Negeri, wawancara pribadi tanggal 25 September 2019.

Trisoko Sugeng Sulistyo, Hakim Pengadilan TUN.wawancara pribadi tanggal 20 Desember 2019.

\section{Peraturan}

Undang-Undang Nomor 5 Tahun 1986 tentang Peradilan Tata Usaha Negara sebagaimana telah diubah terakhir dengan Undang-Undang Nomor 51 Tahun 2009.

Undang-Undang Nomor 31 Tahun 1999 tentang Pemberantasan Tindak Pidana Korupsi

Undang-Undang Nomor 20 Tahun 2001 tentang Perubahan atas Undang-Undang Nomor 31 Tahun 1999 tentang Pemberantasan Tindak Pidana Korupsi

Undang-Undang Nomor 9 Tahun 2004 tentang Perubahan atas Undang-Undang Nomor 5 Tahun 1986 tentang Peradilan Tata Usaha Negara

Undang-Undang Nomor 30 Tahun 2014 tentang Administrasi Pemerintahan.

Instruksi Presiden Nomor 1 Tahun 2016 tentang Percepatan Pelaksanaan Proyek Strategis Nasional.

Peraturan Mahkamah Agung Nomor 4 Tahun 2015 tentang Pedoman Beracara Dalam Penilaian Unsur Penyalahgunaan Wewenang. 